\title{
Rice Response to Nitrogen in Tidal Flooded Non-saline Soil
}

\author{
S M M Islam ${ }^{1, *}$, A Khatun², F Rahman ${ }^{1}$, A T M S Hossain' ${ }^{1}$, U A Naher ${ }^{1}$ and M A Saleque ${ }^{3}$
}

\begin{abstract}
Cultivation of modern varieties (MV) of rice in the coastal non-saline soils of the Asian countries is increasing. Nitrogen $(\mathrm{N})$ deficiency is one of the most nutritional disorders for lowland rice production in Bangladesh. N management recommendation for MV rice in the coastal non-saline soils deserves special attention. A field experiment was conducted for consecutive two years aimed to determine the effect of different nitrogen levels on the yield and nitrogen nutrition of MV rice in coastal non-saline soils of Bangladesh. The field experiment involved five nitrogen levels- 50, 100, 150, 200 and $250 \mathrm{~kg} \mathrm{ha}^{-1}$ including one $\mathrm{N}$-control in randomized complete block design. The application of $150 \mathrm{~kg} \mathrm{~N} \mathrm{ha}^{-1}$ gave the highest yield of $6.76 \mathrm{t} \mathrm{ha}^{-1}$ in 2009 and $6.49 \mathrm{t} \mathrm{ha}^{-1}$ in 2010, respectively. Total nitrogen uptake at $150 \mathrm{~kg} \mathrm{~N}^{2} \mathrm{a}^{-1}$ showed 112 and $116 \mathrm{~kg} \mathrm{ha}^{-1}$ in 2009 and 2010, respectively. Results averaged over two years showed agronomic use efficiency and physiological use efficiency of 22 and $47 \mathrm{~kg} \mathrm{~kg}^{-1}$ with the application of $150 \mathrm{~kg} \mathrm{~N}^{-1}$. The apparent recovery efficiency of applied nitrogen $\left(150 \mathrm{~kg} \mathrm{~N} \mathrm{ha}^{-1}\right)$ had 44 and 50\% in 2009 and 2010, respectively.
\end{abstract}

Key words: Rice yield, tidal flooded soil, nitrogen use efficiency, nitrogen rate

\section{INTRODUCTION}

Coastal and offshore soils occupies about 2.85 million ha in Bangladesh and about 0.73 million ha of the coastal cultivable land has salinity of more than $4.0 \mathrm{dS} / \mathrm{m}$ (Saleque et al., 2010). The coastal non-saline soils are suitable for growing modern rice in winter season. Nitrogen is the most limiting nutrient for rice in tropical Asian soils and almost every farmer has to apply the costly $\mathrm{N}$ fertilizer to get a desirable yield of rice (Fageria et al., 2007). The nitrogen fertilizer requirement in a particular area would not be the same for all type of soils, although their yields would be similar in well-fertilized fields. Modern rice varieties need chemical $\mathrm{N}$ fertilizer application to achieve higher yield. Tropical rice-growing soils have a capacity to supply about $40-60 \mathrm{~kg} \mathrm{~N}$ from its inherent reserve of organic matter and from the biological fixation during rice growth, which is sufficient to produce rice yield of 2-3 $\mathrm{t} \mathrm{ha}^{-1}$ (Saleque et al., 2004). A modern rice variety may yield up to $8 \mathrm{t}$ ha $^{-1}$ in the coastal non-saline soils, but it must be supplied with the proper dose of $\mathrm{N}$ fertilizer (BRRI, 2008).

However, limited researches has been done so far in Bangladesh to recommend optimum $\mathrm{N}$ dose for modern rice in coastal soils of Bangladesh. There are several information on the optimum $\mathrm{N}$ rate of rice production in different countries. Manzoor et al. (2006) reported the most favorable nitrogen rate of 175 $\mathrm{kg} \mathrm{ha}^{-1}$ over three years in clay loam soils of Pakistan. Peng et al. (2006) reported the optimum nitrogen rates of $150-250 \mathrm{~kg} \mathrm{ha}^{-1}$ in soils of China. Kumar et al. (2010) reported most advantageous nitrogen rate of $122 \mathrm{~kg} \mathrm{ha}^{-1}$ for Gangetic soil of India. Fageria and Baligar (2001) reported the optimum nitrogen rates of $78-120 \mathrm{~kg} \mathrm{ha}^{-1}$ in three consecutive years in Inceptisols of Brazil. Saha et al. (2012) reported that $30-60 \mathrm{~kg} \mathrm{~N}^{-1}$ is sufficient to obtain rice yield $\left(5.0 \mathrm{t} \mathrm{ha}^{-1}\right)$ of some promising lines of $\mathrm{T}$. Aman season in Bangladesh. The nitrogen use efficiency and recovery efficiency of $\mathrm{N}$ fertilizer in rice production are rather low. Only 30-40\% of applied $\mathrm{N}$ is used by the crop, however, due to losses through volatilization, denitrification, leaching and run off (De Datta and Buresh, 1989). Increase in fertilizer nutrient input, especially $\mathrm{N}$ fertilizer, has contributed significantly to the improvement of the crop yields in the world (Cassman et al., 2003). 
Most of the farmers in Bangladesh use $\mathrm{N}$ fertilizer for rice production and the dose of $\mathrm{N}$ are being increased year after year to sustain the crop yield. Because of using more fertilizer with benefit in yield, the efficiency and recovery of $\mathrm{N}$ fertilizer are threatened further. Over application of $\mathrm{N}$ fertilizer may actually decrease grain yield by increasing susceptibility to lodging (Pham et al., 2004) and damage from pests and diseases ( $\mathrm{Cu}$ et al., 1996). Judicious use of $\mathrm{N}$ fertilizer in rice requires synchronizing $\mathrm{N}$ fertilizer applications with plant needs. The application of nitrogen fertilizer either in access or less than optimum rate affects both yield and quality of rice to remarkable extent, hence, proper management of crop nutrition is of immense importance. An increase in nitrogen supply increased dry matter and straw yield and N, P and K uptake (Hussain et al., 1989; Mahabari et al., 1996; Nawaz, 1999; Meena et al., 2003).

Salinity level in many coastal soils of the Asian countries (Bangladesh, India, Myanmar, Thailand and Vietnam) is not necessarily high enough to prevent modern rice cultivation. Non-saline coastal lands represent an excellent niche for modern rice production, however, received scant attention in nutrient management option, particularly nitrogen management. Because of tidal sedimentation in every year, coastal non-saline soils possess a good inherent fertility level and nourish the local rice varieties for centuries without any yield reduction. With continuous increasing demand of rice production, MV rice varieties need to be grown in non-saline coastal soils. Our recent studies showed that the tidal flooded coastal soil had no response of rice to applied phosphorus or potassium, but omission of nitrogen greatly limits its yield (BRRI, 2007). However, limited literatures focused on the nitrogen management for coastal non-saline soils. Therefore, the present investigation aimed to compare the yield and nitrogen nutrition of MV rice in tidal non-saline soils under varying levels of nitrogen application.

\section{MATERIALS AND METHODS}

The experiment was conducted at the experimental farm of the Bangladesh Rice Research Institute Regional Station, Barisal, Bangladesh in Boro season during 2009 and 2010 located at $22^{\circ} 43^{\prime} \mathrm{N}$ latitude and $90^{\circ} 27^{\prime} \mathrm{E}$ longitude. The average annual rainfall is 200 $\mathrm{mm}$ with more than $80 \%$ of it occurring from mid-June to the end of September. Mean temperature is the lowest $\left(15^{\circ} \mathrm{C}\right)$ in January and the highest $\left(30^{\circ} \mathrm{C}\right)$ in May.

The soil of the experimental field is clay loam in texture. Initial properties of the surface soil (0-15 cm depth) were as follows: $\mathrm{pH} 6.08$, organic carbon $1.2 \%$, available phosphorus $(\mathrm{P})$ $8.7 \mathrm{mg} \mathrm{kg}^{-1}(0.5 \mathrm{M} \mathrm{NaCO} 3$ extracted $)$ and exchangeable potassium (K) $0.26 \mathrm{meq} / 100 \mathrm{~g}$ soil (Neutral $\quad 1.0 \quad \mathrm{~N} \quad \mathrm{NH}_{4} \mathrm{OAc}$ extracted). Treatments consisted of six nitrogen rates: 0,50 , 100, 150, 200 and $250 \mathrm{~kg} \mathrm{ha}^{-1}$ were applied as urea. A flat dose of P, K and S @ 15-50-10 kg ha1 was applied as soil test basis (STB), respectively. The experiment was laid out in randomized complete block design (RCBD) with three replications. Urea was applied in three equal splits i.e. one-third $\mathrm{N}$ at basal, onethird $\mathrm{N}$ at active tillering stage and one-third $\mathrm{N}$ at 5 to7 days before panicle initiation stage of BRRI dhan29. Phosphorous, K and S fertilizers were applied at final land preparation. The unit plot size was $6 \mathrm{~m} \times 3 \mathrm{~m}$. Fifty-four-day-old seedlings using 2-3 seedlings hill-1 were transplanted at $20 \mathrm{~cm} \times 20 \mathrm{~cm}$ spacing. All intercultural operations were done as and when required. At maturity, the crop was harvested at $5 \mathrm{~m}^{2}$ areas at the centre of each plot for straw and grain yield. The grain yield was adjusted to $14 \%$ moisture content and straw yield as oven dry basis (Yoshida et al., 1976). Nitrogen content from plant samples (grain and straw) was determined by micro Kjeldahl method (Yoshida et al., 1976). Means for the treatment effect and coefficient of variance were analyzed using CropStat7.2 software (IRRI, 2007). 


\section{RESULTS AND DISCUSSIONS}

\section{Grain and straw yield}

Nitrogen control plot showed grain yield of $3.41 \mathrm{t} \mathrm{ha}^{-1}$ in 2009 and $3.22 \mathrm{t} \mathrm{ha}^{-1}$ in 2010. Receiving $50 \mathrm{~kg} \mathrm{~N} \mathrm{ha-1,} \mathrm{the} \mathrm{grain} \mathrm{yield}$ increased to $5.19 \mathrm{t} \mathrm{ha}^{-1}$ in 2009 and $4.44 \mathrm{t} \mathrm{ha}^{-1}$ in 2010 (Table 1). Rice grain yield increased progressively with the increase of nitrogen rate and reached to a maximum (6.76 t ha-1 in 2009 and $6.49 \mathrm{t} \mathrm{ha}^{-1}$ in 2010) with $150 \mathrm{~kg} \mathrm{~N} \mathrm{ha}^{-1}$. Literatures suggested higher paddy yield at higher nitrogen rates (Marazi et al., 1993; Daniel and Wahab, 1994; Bali et al., 1995; Nawaz, 1999; and Meena et al., 2003). Fageria et al. (2011) also reported the highest grain yield was found by nitrogen application of $150 \mathrm{~kg} \mathrm{ha}^{-1}$ and $250 \mathrm{~kg}$ $\mathrm{ha}^{-1}$, respectively. Another study revealed that maximum average grain yield of 20 lowland rice genotypes was obtained at 150 to $200 \mathrm{~kg} \mathrm{~N}$ ha-1 (Singh et al., 1998). Similarly, Dobermann et al. (2000) obtained maximum average grain yield in the dry season at IRRI, Philippines with 120 to $150 \mathrm{~kg} \mathrm{~N} \mathrm{ha}^{-1}$. Singh et al. (2007) observed $120 \mathrm{~kg} \mathrm{~N} \mathrm{ha}^{-1}$ as an optimum dose for a yield level of 7.45 and $6.80 \mathrm{t} \mathrm{ha}^{-1}$ in two consecutive years for direct wet season rice in IndoGangetic plain of Ludhiana, India.

Table 1. Effect of $\mathbf{N}$ fertilizer rates on grain and straw yields of BRRI dhan29 in BRRI RS farm, Barisal, Boro 2009-10

\begin{tabular}{lcrrrrr}
\hline N rate $\left(\mathrm{kg} \mathrm{ha}^{-1}\right)$ & \multicolumn{2}{c}{ Panicle $\mathrm{m}^{-2}$} & \multicolumn{2}{c}{ Grain yield $\left(\mathrm{t} \mathrm{ha}^{-1}\right)$} & \multicolumn{2}{c}{ Straw yield $\left(\mathrm{t} \mathrm{ha}^{-1}\right)$} \\
\hline & 2009 & 2010 & 2009 & 2010 & 2009 & 2010 \\
\hline $\mathrm{N}_{0}$ & 183 & 141 & 3.41 & 3.22 & 3.20 & 2.33 \\
$\mathrm{~N}_{50}$ & 238 & 194 & 5.19 & 4.44 & 4.07 & 3.20 \\
$\mathrm{~N}_{100}$ & 304 & 196 & 5.82 & 5.40 & 6.78 & 4.25 \\
$\mathrm{~N}_{150}$ & 332 & 236 & 6.76 & 6.49 & 6.64 & 5.18 \\
$\mathrm{~N}_{200}$ & 368 & 227 & 6.66 & 6.48 & 6.57 & 5.04 \\
$\mathrm{~N}_{250}$ & 404 & 271 & 4.91 & 6.31 & 7.57 & 4.97 \\
LSD $_{0.05}$ & 34 & 13 & 0.70 & 0.46 & 2.31 & 0.39 \\
\hline
\end{tabular}

Nitrogen application at the rate of 200 and 250 $\mathrm{kg} \mathrm{ha}^{-1}$ declined rice yield compared to that of $150 \mathrm{~kg} \mathrm{~N} \mathrm{ha-1}$. Rice grain yield showed quadratic response with the rates of nitrogen application in both 2009 and 2010 (Figure 1). Response equation $(Y=3.31+0.044 N-0.00015$ $N^{2}, \mathrm{R}^{2}=0.94$ in 2009 and $Y=3.13+0.032 N-$ $0.00008 N^{2}, R^{2}=0.99$ in 2010) explained the quadratic relationship between applied $\mathrm{N}$ and grain yield. Differentiating the quadratic appeared as $145 \mathrm{~kg} \mathrm{ha}^{-1}$ in 2009 and $200 \mathrm{~kg} \mathrm{ha}^{-1}$ in 2010, respectively.

Data points in Figure 1 showed insignificant yield difference between $150 \mathrm{~kg} \mathrm{~N}$ ha-1 and $200 \mathrm{~kg} \mathrm{~N} \mathrm{ha}^{-1}$ both in 2009 and 2010. But the quadratic equation significantly explained the relationship between applied $\mathrm{N}$ and grain yield $\left(\mathrm{R}^{2}=0.94\right.$ in 2009 and 0.99 in 2010). The predicted optimum $\mathrm{N}$ dose appeared to be an overestimation in 2010 . equation of yield response with respect to applied $\mathrm{N}$ doses, the economic optimum dose

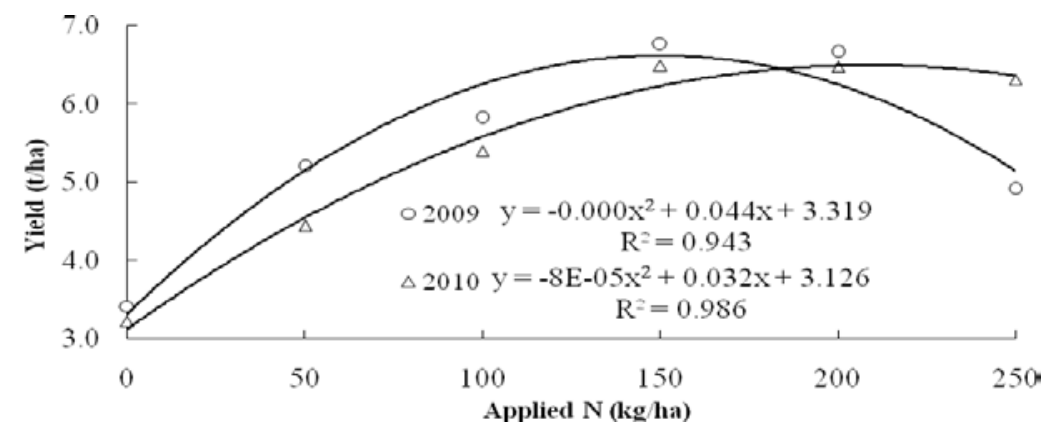

Fig. 1. Quadratic relationship between applied nitrogen and grain yield of rice in 2009 and 2010 under tidal flooded ecosystem 
The experimental field soil had a potential nitrogen supplying capacity of $94 \mathrm{~kg} \mathrm{ha}^{-1}$ and capable of supporting $8.50 \mathrm{t} \mathrm{ha}^{-1}$ yield of MV rice according to QUEFTS model (Janssen et al., 1990). The calculated dose of $\mathrm{N}$ appeared for the estimated yield level was $152 \mathrm{~kg} \mathrm{ha}^{-1}$, which agrees the predicted optimum dose of $\mathrm{N}$ from the response trial. The observed yields in both the years were about $2 \mathrm{t} \mathrm{ha}^{-1}$ lower than the predicted achievable yield. The lower yield might be attributed to the aged seedlings in 2009 and insect (stem borer) infestation in both the years. The application of $\mathrm{N}$ increased straw yield significantly in both the years, except the $\mathrm{N}_{50}$ treatment in 2009 (Table 1). The variation of straw yield between $\mathrm{N}$ control and $\mathrm{N}_{50}$ treatment was insignificant in 2009. Other $\mathrm{N}$ treatments showed insignificant straw yield in 2009. In 2010, straw yield increased with the increase of $\mathrm{N}$ rate up to $150 \mathrm{~kg} \mathrm{~N}$ ha- $\mathrm{kg}^{-1}$ then decreased insignificantly. These might be associated with higher nitrogen fertilizer application and tiller or panicle production.

\section{Nitrogen nutrition and uptake}

The $\mathrm{N}$ concentration in grain varied significantly among the treatments (Table 2). The grain $\mathrm{N}$ concentration in $\mathrm{N}$-control plot observed $0.87 \%$, which increased to $1.06 \%$ in 2009 and $1.03 \%$ in 2010 receiving $50 \mathrm{~kg} \mathrm{~N} \mathrm{ha}^{-1}$. The grain $\mathrm{N}$ concentration increased progressively with the increase of $\mathrm{N}$ rates. The highest seed $\mathrm{N}$ concentration was obtained from $200 \mathrm{~kg} \mathrm{~N} \mathrm{ha}^{-1}$ in 2009 (1.18\%) and $250 \mathrm{~kg}$ $\mathrm{N}$ ha $^{-1}$ in 2010 (1.42\%). The straw N concentration varied from 0.50 to $0.60 \%$ in 2009 and from 0.52 to $0.78 \%$ in 2010 ; however, the values were statistically similar (Table 2).

Grain N uptake in the N control plots had 29.71 and $28.20 \mathrm{~kg} \mathrm{ha}^{-1}$ in 2009 and 2010, respectively (Table 3). The application of $\mathrm{N}$ increased grain $\mathrm{N}$ uptake significantly in both the years. Increasing the $\mathrm{N}$ rates increased grain $\mathrm{N}$ uptake progressively and reached maximum to $78.62 \mathrm{~kg} \mathrm{ha}^{-1}$ in 2009 and $89.87 \mathrm{~kg}$ $\mathrm{ha}^{-1}$ in 2010. Straw $\mathrm{N}$ uptake varied from 16.95 to $40.87 \mathrm{~kg} \mathrm{ha}^{-1}$ in 2009 and from 12.35 to 38.74 $\mathrm{kg} \mathrm{ha}^{-1}$ in 2010, respectively. In both the years,
Table 2. Concentration of $\mathbf{N}$ in grain and straw of BRRI dhan29 in BRRI RS farm, Barisal, Boro 2009-10

\begin{tabular}{lcccc}
\hline $\begin{array}{c}\text { N rate (kg } \\
\text { ha }\end{array}$ & \multicolumn{2}{c}{ Grain N (\%) } & \multicolumn{2}{c}{ Straw N (\%) } \\
\hline & 2009 & 2010 & 2009 & 2010 \\
\hline $\mathrm{N}_{0}$ & 0.87 & 0.87 & 0.53 & 0.52 \\
$\mathrm{~N}_{50}$ & 1.06 & 1.03 & 0.61 & 0.53 \\
$\mathrm{~N}_{100}$ & 1.11 & 1.27 & 0.50 & 0.58 \\
$\mathrm{~N}_{150}$ & 1.12 & 1.30 & 0.56 & 0.62 \\
$\mathrm{~N}_{200}$ & 1.18 & 1.36 & 0.57 & 0.67 \\
$\mathrm{~N}_{250}$ & 1.13 & 1.42 & 0.55 & 0.78 \\
$\mathrm{LSD}_{0.05}$ & 0.06 & 0.20 & ns & ns \\
\hline
\end{tabular}

the N-control plots had the lowest $\mathrm{N}$ uptake and the plots that received the highest dose of $\mathrm{N}$ gave the highest $\mathrm{N}$ uptake in rice straw. Total $\mathrm{N}$ uptake varied from 46.66 to $115.69 \mathrm{~kg} \mathrm{ha}^{-1}$ in 2009 and from 40.55 to $128.61 \mathrm{~kg} \mathrm{ha}^{-1}$ in 2010. The predicted N supplying capacity of $94 \mathrm{~kg}$ ha ${ }^{-1}$ from the QUEFTS model corroborated the magnitude of $\mathrm{N}$ uptake $\left(46.66 \mathrm{~kg} \mathrm{ha}^{-1}\right.$ in 2009 and $40.55 \mathrm{~kg} \mathrm{ha}^{-1}$ in 2010) in the N-control plots assuming about $50 \%$ of $\mathrm{N}$ recovery of the soil $\mathrm{N}$ by lowland rice. The requirement of rice for $\mathrm{N}$ fertilizer can, however, vary greatly from location to location, season to season, and year to year because of high variability among fields, seasons, and years in N-supplying capacity of soil (Cassman et al., 1996; Dobermann et al., 2003). The predicted N supplying capacity from the QUEFTS model supported the extent of $\mathrm{N}$ uptake $50 \%$ and $43 \%$ in the $\mathrm{N}$-control plots.

\section{Nitrogen use efficiency}

Agronomic use efficiency (AUE) of $\mathrm{N}$ varied from 6.0 to $35.7 \mathrm{~kg} \mathrm{~kg}^{-1}$ in 2009 and from 12.36 to $24.40 \mathrm{~kg} \mathrm{~kg}^{-1}$ in 2010 (Table 4). The AUE was the highest at $50 \mathrm{~kg} \mathrm{~N}^{-1}$ and then decreased progressively with the increase of $\mathrm{N}$ rates in both the years. The $150 \mathrm{~kg} \mathrm{~N} \mathrm{ha}^{-1}$, which was the desired level of $\mathrm{N}$ application for tidal soils, had AUE of 22.3 and $21.8 \mathrm{~kg} \mathrm{~kg}^{-1}$ in 2009 and 2010, respectively. Fageria and Baligar (2001) reported that AUE was $23 \mathrm{~kg}$ grain produced per $\mathrm{kg}$ of $\mathrm{N}$ applied across $\mathrm{N}$ rates. Yoshida (1981) reported agronomic efficiency in lowland rice in the tropics in the range of 15 to 
Table 3. Nitrogen uptake in BRRI dhan 29 as influenced by different nitrogen fertilizer rates in BRRI farm Barisal, Boro 2009-10.

\begin{tabular}{lcccccc}
\hline $\begin{array}{c}\text { N rate } \\
\left(\mathrm{kg} \mathrm{ha}^{-1}\right)\end{array}$ & \multicolumn{2}{c}{$\begin{array}{c}\text { Grain N uptake } \\
\left(\mathrm{kg} \mathrm{ha}^{-1}\right)\end{array}$} & \multicolumn{2}{c}{$\begin{array}{c}\text { Straw N uptake } \\
\left(\mathrm{kg} \mathrm{ha}^{-1}\right)\end{array}$} & \multicolumn{2}{c}{$\begin{array}{c}\text { Total N uptake } \\
\left(\mathrm{kg} \mathrm{ha}^{-1}\right)\end{array}$} \\
\hline & 2009 & 2010 & 2009 & 2010 & 2009 & 2010 \\
\hline $\mathrm{N}_{0}$ & 29.71 & 28.20 & 16.95 & 12.35 & 46.66 & 40.55 \\
$\mathrm{~N}_{50}$ & 55.11 & 46.24 & 24.79 & 17.02 & 79.90 & 63.26 \\
$\mathrm{~N}_{100}$ & 64.26 & 69.11 & 35.46 & 24.91 & 99.73 & 94.02 \\
$\mathrm{~N}_{150}$ & 75.75 & 84.03 & 36.40 & 32.12 & 112.15 & 116.15 \\
$\mathrm{~N}_{200}$ & 78.62 & 88.41 & 37.07 & 33.77 & 115.69 & 122.18 \\
$\mathrm{~N}_{250}$ & 55.42 & 89.87 & 40.87 & 38.74 & 96.29 & 128.61 \\
LSD $_{0.05}$ & 7.58 & 13.27 & 15.00 & 4.97 & 20.11 & 15.43 \\
\hline
\end{tabular}

$25 \mathrm{~kg}$ grain produced per $\mathrm{kg}$ of applied $\mathrm{N}$. Physiological $\mathrm{N}$ use efficiency (PUE) varied from 30.2 to $53.7 \mathrm{~kg} \mathrm{~kg}^{-1}$ in 2009 and 38.6 to 53.7 $\mathrm{kg} \mathrm{kg}^{-1}$ in 2010. As a rule, physiological $\mathrm{N}$ use efficiency decreased with the increasing $\mathrm{N}$ rates.

Reciprocal of internal $\mathrm{N}$ use efficiency $(\mathrm{kg}$ $\mathrm{N}$ required to produce $1 \mathrm{t}$ of grain) varied from 13.67 to $19.60 \mathrm{~kg} \mathrm{t}^{-1}$ in 2009 and from 12.59 to $20.38 \mathrm{~kg} \mathrm{t}^{-1}$ in 2010 (Table 4). Reciprocal of internal $\mathrm{N}$ use efficiency (RIUE) showed the lowest in $\mathrm{N}$-control and the highest with the highest rate of $\mathrm{N}$. The RIUE at $150 \mathrm{~kg} \mathrm{~N}$ ha-1 had 16.59 and $17.90 \mathrm{~kg} \mathrm{t}^{-1}$ in 2009 and 2010, respectively. Buresh et al. (2010) reported mean
RIUE of $16.4 \mathrm{~kg} \mathrm{t}^{-1}$ with full fertilization and $12.8 \mathrm{~kg} \mathrm{t}^{-1}$ in-N plots.

Apparent recovery efficiency of $\mathrm{N}$ varied from 19.9 to $66.5 \%$ in 2009 and 35.22 to $53.47 \%$ in 2010 (Table 4). The apparent recovery efficiency (ARE) was higher at $50 \mathrm{~kg} \mathrm{~N}$ ha-1 compared to the other higher doses of $\mathrm{N}$ and the highest $\mathrm{N}$ dose showed the lowest $\mathrm{N}$ recovery. The $150 \mathrm{~kg} \mathrm{~N}^{-1}$ treatment showed 43.7 and $50.40 \% \mathrm{~N}$ recovery in 2009 and 2010, respectively. For lowland rice in the tropics ARE is $30-50 \%$ of applied $\mathrm{N}$ depending on season, yield level, the rate and timing of $\mathrm{N}$ application (Yoshida, 1981; De Datta, 1986). Fageria and Baligar (2001) also reported that

Table 4. Agronomic use efficiency, physiological efficiency, internal efficiency and recovery of $\mathbf{N}$ by BRRI dhan29 in BRRI RS farm, Barisal, Boro 2009-10

\begin{tabular}{ccccccccc}
\hline $\begin{array}{c}\mathrm{N} \text { rate } \\
\left(\mathrm{kg} \mathrm{ha}^{-1}\right)\end{array}$ & \multicolumn{2}{c}{$\begin{array}{c}\text { Agronomic } \\
\text { efficiency } \\
\left(\mathrm{kg} \mathrm{kg}^{-1}\right)\end{array}$} & \multicolumn{2}{c}{$\begin{array}{c}\text { Physiological } \\
\text { efficiency } \\
\left(\mathrm{kg} \mathrm{kg}^{-1}\right)\end{array}$} & $\begin{array}{c}\text { Reciprocal internal use } \\
\text { efficiency } \\
\left(\mathrm{kg} \mathrm{kg}^{-1}\right)\end{array}$ & $\begin{array}{c}\text { Apparent recovery } \\
\text { efficiency } \\
(\%)\end{array}$ \\
\hline & 2009 & 2010 & 2009 & 2010 & 2009 & 2010 & 2009 & 2010 \\
\hline $\mathrm{N}_{0}$ & - & - & - & - & 13.67 & 12.59 & - & - \\
$\mathrm{N}_{50}$ & 35.7 & 24.40 & 53.7 & 53.72 & 15.37 & 14.24 & 66.5 & 45.42 \\
$\mathrm{~N}_{100}$ & 24.1 & 21.80 & 45.4 & 40.77 & 17.12 & 17.41 & 53.1 & 53.47 \\
$\mathrm{~N}_{150}$ & 22.3 & 21.80 & 51.1 & 43.25 & 16.59 & 17.90 & 43.7 & 50.40 \\
$\mathrm{~N}_{200}$ & 16.2 & 16.30 & 47.1 & 39.94 & 17.37 & 18.85 & 34.5 & 40.81 \\
$\mathrm{~N}_{250}$ & 6.0 & 12.36 & 30.2 & 38.60 & 19.60 & 20.38 & 19.9 & 35.22 \\
\hline
\end{tabular}

ARE was 39\% across $\mathrm{N}$ rates in flooded rice cultivar Metica 1.

\section{CONCLUSIONS}

Nitrogen management is essential to reduce $\mathrm{N}$ losses, improve $\mathrm{N}$ use efficiency and obtain higher rice yield. The optimum $\mathrm{N}$ dose for tidal soils in Boro season might be $150 \mathrm{~kg} \mathrm{ha}^{-1}$ for rice. The application of $150 \mathrm{~kg} \mathrm{~N} \mathrm{ha-1}$ showed AUE, PUE and RIUE for $\mathrm{N}$ as 22.3 and $21.8 \mathrm{~kg} \mathrm{~kg}^{-1}, 51.1$ and $43.25 \mathrm{~kg} \mathrm{~kg}^{-1}, 16.59$ and $17.90 \mathrm{~kg} \mathrm{~kg}^{-1}$ in 2009 and 2010, respectively. However, the economic optimum rate of $\mathrm{N}$ for BRRI dhan29 appeared as about $173 \mathrm{~kg} \mathrm{~N}^{-1}$ averaged over two years. Thus, sufficient $\mathrm{N}$ application is one of the strategies to boost straw yield and consequently grain yield in tidal flooded non-saline soil. 


\section{REFERENCES}

BRRI (Bangladesh Rice Research Institute). 2007. Annual Report for 2006-2007. BRRI, Gazipur 1701. 177-178.

BRRI (Bangladesh Rice Research Institute). 2008. Annual Report for 2007-2008. BRRI, Gazipur 1701.

Buresh, R J, M F Pampolino and C Witt. 2010. Fieldspecific potassium and phosphorus balances and fertilizer requirements for irrigated rice-based cropping systems. Plant Soil 335: 35-64.

Cassman, K G, A Dobermann, D T Walters and H S Yang. 2003. Meeting cereal demand while protecting natural resources and improving environmental quality. Ann. Rev. Environ. Resour. 28: 315-358.

Cassman, K G, A Dobermann, P C S Cruz, G C Gines M I Samson, J P Descalsota, J M Alcantara M A Dizon and D C Olk. 1996. Soil organic matter and the indigenous nitrogen supply of intensive irrigated rice systems in the tropics. Plant Soil 182: 267-278.

Cu, R M, T W Mew, K G Cassman and P S Teng. 1996. Effect of sheath blight on yield in tropical, intensive rice production system. Plant Disease 80:1103-1108.

De Datta, S K. 1986. Improving nitrogen fertilizer efficiency in lowland rice in Tropical Asia.Fert. Res. 9: 171-186.

De Datta, S K and R J Buresh. 1989. Integrated nitrogen management in irrigated rice. Adv. Soil Sci. 10:143-169.

Dobermann, A, C Witt, S Abdulrachman, H C Gines, R Nagarajan, T T Son, P S Tan, G H Wang, N V Chien, V T K Thoa, C V Phung, P Stalin, P Muthakrishnan, V Ravi, M Babu, G C Simbahan and M A AAdviento. 2003. Soil fertility and indigenous nutrient supply in irrigated rice domains of Asia. Agron. J. 95: 913- 923.

Dobermann, A, D Dawe, R P Roetter and K G Cassman. 2000. Reversal of rice yields decline in a long term continuous cropping experiment. Agron. J. 92: 633-643.

Fageria, N K and V C Baligar. 2001. Lowland rice response to nitrogen fertilization.Comm. Soil Sci. Plant Anal. 32: 405-1429.

Fageria, N K and A B Santos and V C Baligar. 1997. Phosphorus soil test calibration for lowland rice on an Inceptisol, Agron. J.89: 737-742.

Fageria, N K, A Moreira and A M Coelho. 2011. Yield and yield components of upland rice as influenced by nitrogen sources. J. Plant Nut. 34: 361-370.

Hussain, T, G Jilani and A Ghaffar. 1989. Influence of rate and time of nitrogen application on growth and yield of rice in Pakistan. Inter. Rice. Res. Newsletter. 18p.

International Rice Research Institute (IRRI), “CropStat for Windows 7.2," Dapo, Metro Manila. 2007.

Janssen, B H, F C T Guiking, D van der Eijk, E M A Smaling, J Wolf and H van Reuler. 1990. A system for quantitative evaluation of the fertility of tropical soils (QUEFTS).Geoderma 46: 299-318.
Kumar, D, C Devakumar, R Kumar, P A Das, P Panneerselvam and Y S Shivay. 2010. Effect of neem-oil coated prilled urea with varying thickness of neem-oil coating and nitrogen rates on productivity and nitrogen-use efficiency of lowland irrigated rice under Indo-Gangetic plains. J. Plant Nut. 33: 1939-1959.

Mahabari, M B, D S Patil and S D Kalke. 1996. Yield and uptake of nutrients as influenced by the method and time of application of nitrogen fertilizer under flood prone rice. Soils and Crops 6: 27-30.

Manzoor, Z, T H Awan, M A Zahid and F A Faiz. 2006. Response of rice crop (super basmoti) to different nitrogen levels. J. Anim. Pl. Sci. 16: 52-55.

Meena, S L, S Surendra, Y S Shivay and S Singh. 2003. Response of hybrid rice (Oryza sativa) to nitrogen and potassium application in sandy clay loam soils. Indian J. Agric. Sci. 73: 8-11.

Nawaz, H M A. 1999. Effect of various levels and methods of nitrogen application on nitrogen use efficiency in rice Super Basmati. MSc Thesis Deptt.Agron, Univ. Agric., Faisalabad.

Peng, S, R J Buresh, J Huang, J Yang, Y Zou, X Zhong, G Wang and F Zhang. 2006. Strategies for overcoming low agronomic nitrogen use efficiency in irrigated rice systems in China. Field Crops Res. 96: 37-47.

Pham, Q D, A Abe, M S Hirano Sagawa and E Kuroda. 2004. Analysis of lodging-resistant characteristics of different rice genotypes grown under the standard and nitrogen-free basal dressing accompanied with sparse planting density practices. Plant Prod. Sci. 7: 243-251.

Saha, P K, S M M Islam, M Akter and S K Zaman. 2012. Nitrogen response behaviour of developed promising lines of T. Aman rice. Bangladesh J. Agril. Res. 37: 207-213.

Saleque, M A, U A Naher, N NChoudhury and A T M $S$ Hossain. 2004.Variety-specific nitrogen fertilizer recommendation for lowland rice. Comm. Soil Sci. Plant Anal. 35: 1891-1903.

Saleque, M A, M K Uddin, M A Salam, A M Ismail and S M Haefele. 2010. Soil characteristics of saline and non-saline deltas of Bangladesh. pp (144-153). In. Hoanh, C T, B W Szuster, K Suvan-Pheng, A M Ismail and A W Noble. (Eds.) Tropical deltas and costal zones. CABI, UK.

Singh, U, J K Ladha, E G Castillo, G Punjalan, A TirolPadre, M Duqueza. 1998. Genotypic variation in nitrogen use efficiency in medium and long duration rice. Field Crop Res. 58: 35-53.

Singh, Y, R K Gupta, B Singh and S Gupta. 2007. Efficient management of fertilizer nitrogen in wet direct-seeded rice (Oryza sativa) in northwest India. Indian J. Agri. Sci. 77: 56-564.

Yoshida, S, D A Forno, J H Cock and K A Gomez. 1976. Laboratory Manual for physiological Studies of Rice. $3^{\text {rd }}$ ed. International Rice research Institute. Manila, Philippines.

Yoshida, S. 1981. Fundamentals of Rice crop science, IRRI, Los Banos, Philippines. 269-270. 